\begin{tabular}{c|l|l|l}
$\begin{array}{c}\text { Case Reports in } \\
\text { Oncology }\end{array}$ & $\begin{array}{l}\text { Case Rep Oncol 2011;4:222-228 } \\
\text { DOl: 10.1159/000327845 }\end{array}$ & $\begin{array}{l}\text { Published online: } \\
\text { April 6, 2011 }\end{array}$ & $\begin{array}{l}\text { O 2011 S. Karger AG, Basel } \\
\text { ISSN 1662-6575 } \\
\text { www.karger.com/cro }\end{array}$ \\
\hline
\end{tabular}

\title{
Biphasic Synovial Sarcoma of the Extremity: Quadruple Approach of Isolated Limb Perfusion, Surgical Ablation, Adipofascial Perforator Flap and Radiation to Avoid Amputation
}

\author{
Lars Steinstraesser $^{\mathrm{a}} \quad$ Reena Agarwal $^{\mathrm{a}}$ Ingo Stricker ${ }^{\mathrm{b}}$ \\ Hans-Ulrich Steinau ${ }^{a}$ Sammy Al-Benna ${ }^{a}$

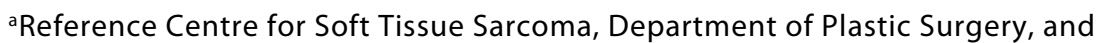 \\ bInstitute of Pathology, BG University Hospital Bergmannsheil, Ruhr University Bochum, \\ Bochum, Germany
}

\section{Key Words}

Synovial sarcoma - Amputation · Isolated limb perfusion · Surgical ablation · Adipofascial perforator flap $\cdot$ Radiation

\begin{abstract}
Synovial sarcoma is a rare type of soft tissue sarcoma that occurs mostly in young adults, and it is always regarded as a high-grade tumor. Here, we report the case of a 31-year-old German Caucasian male with synovial sarcoma of the wrist who was offered amputation at his local hospital. After referral to our Reference Centre for Soft Tissue Sarcoma, the quadruple approach of isolated limb perfusion, surgical ablation, adipofascial perforator flap and radiation avoided amputation and enabled preservation of good hand function with no evidence of recurrence or metastasis after 1 year.
\end{abstract}

\section{Introduction}

Synovial sarcomas are malignant high-grade soft tissue neoplasm sarcomas that occur mostly in young adults [1-12]. They constitute $6.4 \%$ out of the 2,518 soft tissue sarcomas evaluated at our Reference Centre for Soft Tissue Sarcoma (fig. 1). We present a case of synovial sarcoma of the wrist where the quadruple approach of isolated limb perfusion, surgical ablation, adipofascial perforator flap and radiation avoided amputation and enabled preservation of good hand function. 


\section{Case Report}

A 31-year-old, fit and well, Caucasian male presented to his local hospital with a 3-month history of classic symptoms of carpal tunnel syndrome in the left non-dominant hand. Nerve conduction studies confirmed this diagnosis. At the time of the routine carpal tunnel decompression, a $2.5-\mathrm{cm}$ lump was noted within the tunnel and was enucleated. Reference pathology results showed an incompletely excised G2 biphasic synovial sarcoma. His local hospital proposed amputation which he refused, and thus, he was referred to our Reference Centre for Soft Tissue Sarcoma. After multidisciplinary review, preoperative extremity perfusion was recommended prior to surgical ablation followed by low-dose radiotherapy. Isolated extremity perfusion of the left upper limb via the brachial artery was performed with melphalan and berumon. Post-extremity perfusion, an MRI scan performed at our centre, demonstrated only scar tissue in the carpal tunnel and no residual lump. He was taken to theatre for wide local ablation. This included a flexor tenosynovectomy and excision of the previous scar along with a rim of thenar and the hypothenar musculature (fig. 2). This led to the exposure of the ulnar neurovascular pedicle, the median nerve, and the radial artery. In order to protect these structures from potential future radiation injury, a pedicled adipofascial distal ulnar artery perforator flap was raised and inserted anterior to these vital structures (fig. 3). The hand was immobilized in a splint for 2 weeks. The patient was discharged home on postoperative day 5 with no complications. Reference pathology revealed fibrous tissue with Salzer-Kuntschik regression grade 1, showing no evidence of viable tumor cells ( $\underline{\text { fig. }}$ ). The patient received low-dose adjuvant radiation therapy of the primary tumor site.

\section{Discussion}

Synovial sarcomas are malignant high-grade soft tissue neoplasms [1-12]. They constitute $6.5 \%$ out of the 2,056 soft tissue sarcomas evaluated at our Reference Centre for Soft Tissue Sarcoma (fig. 3). Synovial sarcoma is the most common malignant nonrhabdomyosarcoma soft-tissue sarcoma in children, with approximately 1 of 3 cases occurring in the first 2 decades of life [9-12]. This malignancy usually involves the extremities, especially the lower extremities around the knees and ankles [1-12]. Other sites are the shoulder and hip. It occurs primarily in the para-articular regions, usually in close association with tendon sheaths, bursae, and joint capsules [1-12]. In contrast to its name, synovial sarcoma occurs in areas with no apparent relation to synovial structures, such as the larynx, heart, pericardium, pleura, lung, mediastinum, peritoneal cavity and abdominal wall. Its microscopic resemblance to the developing synovium was suggested early in the literature, but its origin from preformed synovial tissues has never been substantiated and remains unclear [6]. Thus, due to the similarity between cells of this tumor and primitive synoviocytes, the term synovial sarcoma has been used [6]. Histologically, synovial sarcoma is characterized by epithelial-like and spindle cell components arranged in a biphasic or monophasic pattern, and a poorly differentiated form of synovial sarcoma has also been described recently [6]. The pathologic features of synovial sarcoma are identical in children and adults. In addition, the translocation $t(X ; 18)$ has been noted in more than $90 \%$ of cases $[6,14]$. Although synovial sarcomas can be graded according to mitotic index, percent necrosis, and tumor differentiation, they should always be regarded as high-grade sarcomas [6, 12-14].

Synovial sarcomas are locally aggressive and have a higher metastatic potential than other soft tissue sarcomas and the overall prognosis of patients is poor because of systemic metastasis [1-12]. Despite intensive multimodal therapy, such as surgery, chemotherapy, and radiotherapy, none of these therapies have substantially changed the outcome of patients with malignant tumors $[3,4]$. Local recurrence and/or metastatic disease is found in approximately $80 \%$ of patients $[1-12]$. 
Surgical ablation with an adequate margin is the definitive choice of treatment for primary tumors and has been shown to control local recurrence $[1-12,15]$. Due to proximity to the joints, the ablation can consist of either tenosynovectomy and/or postoperative radiotherapy and/or chemotherapy or amputation. If ablation and tenosynovectomy are selected by the patient in order to retain maximal function, this may lead to inadequate soft tissue cover over tendons and neurovascular pedicles.

Disseminated distant metastasis is the major cause of poor outcome, and several reports describing the results of current therapy showed a 5-year survival rate of around 27 to $55 \%$ [1-12]. The efficacy of adjuvant chemotherapy is still a matter of debate, and the development of a new therapeutic approach is required to improve the prognosis $[3$, 4]. This case presented a unique situation of a biphasic synovial sarcoma that was treated with enucleation in the past. As the patient wanted to retain his hand, wide ablation, with careful attention to margins, including flexor tenosynovectomy, was performed with neoadjuvant isolated limb perfusion chemotherapy and low-dose postoperative radiotherapy to produce optimal local control. To cover the vital structures of the wrist, a perforatorbased adipofascial flap was raised from the forearm and turned over to cover these structures as well as the suture line for the subsequent postoperative radiotherapy. At the 1-year follow-up, there was no evidence of recurrence or metastasis.

Synovial sarcomas should always be regarded as high-grade soft tissue sarcomas [6, 14, 15]. It is important to obtain adequate ablative margins and prevent local recurrence. In anatomically critical regions of the hand and wrist, the surgeon should attain up to clear margins whenever feasible, and every effort should be made to clear the surgical margin. When anatomic considerations and patient wishes prevent the surgeon from achieving adequate surgical margins due to proximity to critical structures, isolated limb perfusion and radiotherapy must be considered and potentially may prevent amputation. In addition to soft tissue coverage, flaps that receive a sufficient blood supply are known to prevent the occurrence of radiation injury [16].

The reconstructive surgeon's armamentarium has expanded to match the increasing role of ablative distal extremity surgery. Anticipation of the intended ablative procedure, knowledge of reconstruction options specific to the patient, possible premorbid conditions and patient wishes for limb preservation must all be considered before surgery. Multidisciplinary discussion of adjuvant therapies that may prevent amputation must occur prior to surgery. In our case, isolated limb perfusion, wide ablation and adipofascial perforator flap reconstruction to reduce the risk of postoperative radiation injury have succeeded in preserving extremity function, and there was no evidence of recurrence or metastasis after 1 year. 


\begin{tabular}{c|l|l|l}
$\begin{array}{c}\text { Case Reports in } \\
\text { Oncology }\end{array}$ & $\begin{array}{l}\text { Case Rep Oncol 2011;4:222-228 } \\
\text { DOI: 10.1159/000327845 }\end{array}$ & $\begin{array}{l}\text { Published online: } \\
\text { April 6, 2011 }\end{array}$ & $\begin{array}{l}\text { O 2011 S. Karger AG, Basel } \\
\text { ISSN 1662-6575 } \\
\text { www.karger.com/cro }\end{array}$ \\
\hline
\end{tabular}

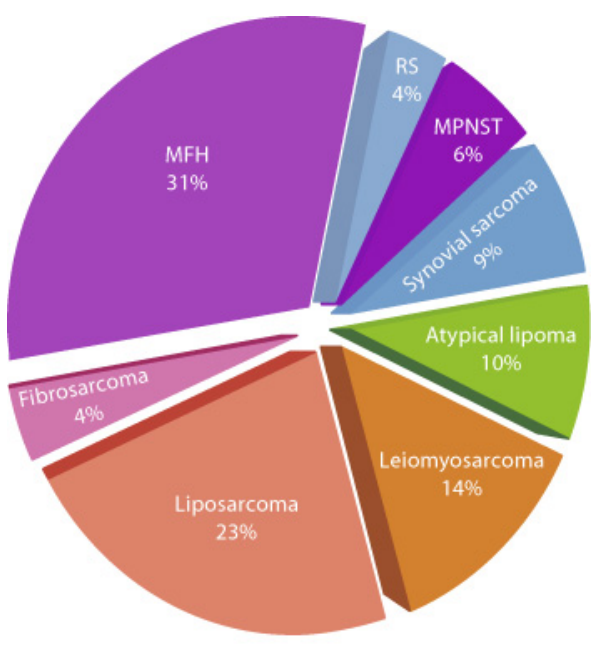

1990-2010: $\mathrm{n}=2,518$

Fig. 1. Case distribution of soft tissue sarcomas at the BG University Hospital Bergmannsheil, Bochum, Germany. MFH = Malignant fibrous histiocytoma; MPNST = malignant peripheral nerve sheath tumor; RS = rhabdomyosarcoma.

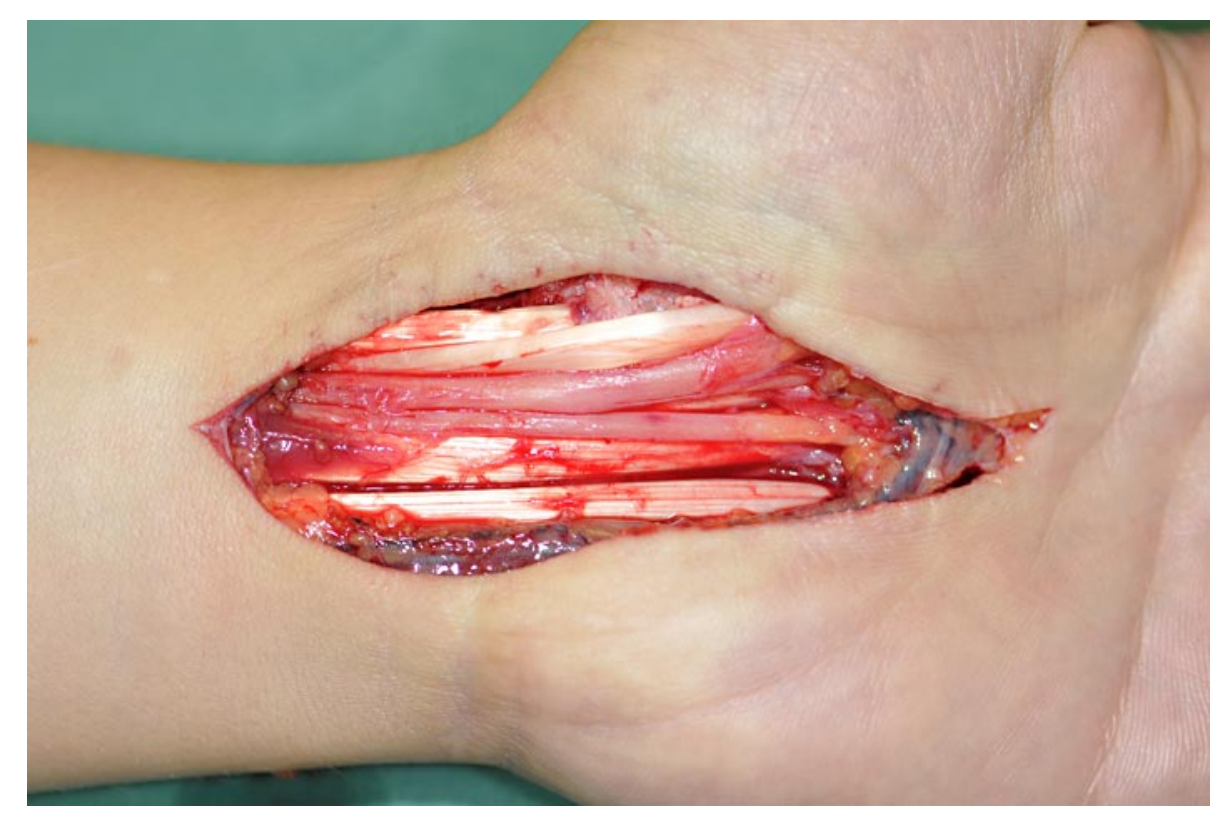

Fig. 2. Defect post-flexor tenosynovectomy and wide ablation. 


\begin{tabular}{c|l|l|l}
$\begin{array}{c}\text { Case Reports in } \\
\text { Oncology }\end{array}$ & $\begin{array}{l}\text { Case Rep Oncol 2011;4:222-228 } \\
\text { DOI: 10.1159/000327845 }\end{array}$ & $\begin{array}{l}\text { Published online: } \\
\text { April 6, 2011 }\end{array}$ & $\begin{array}{l}\text { O 2011 S. Karger AG, Basel } \\
\text { ISSN 1662-6575 } \\
\text { www.karger.com/cro }\end{array}$ \\
\hline
\end{tabular}

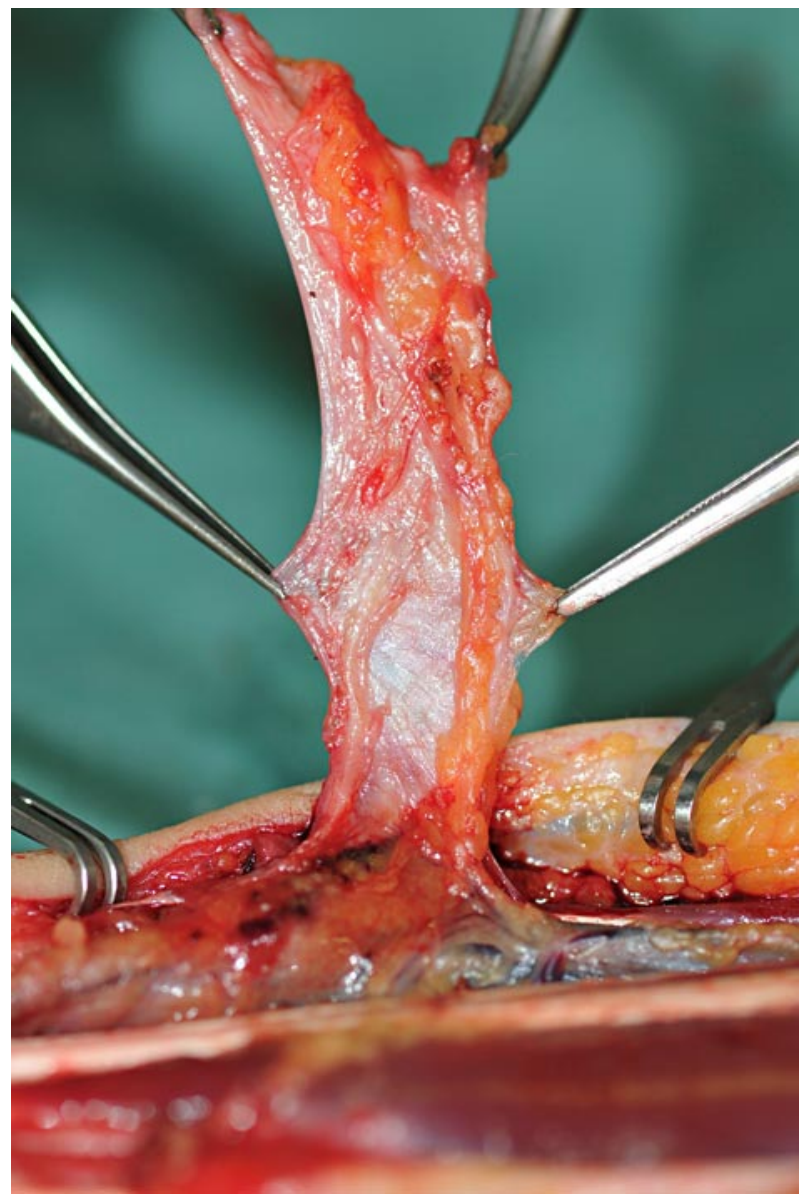

Fig. 3. Pedicled adipofascial distal ulnar artery perforator flap. 


\begin{tabular}{c|l|l|l}
$\begin{array}{c}\text { Case Reports in } \\
\text { Oncology }\end{array}$ & $\begin{array}{l}\text { Case Rep Oncol 2011:4:222-228 } \\
\text { DOI: 10.1159/000327845 }\end{array}$ & $\begin{array}{l}\text { Published online: } \\
\text { April 6, 2011 }\end{array}$ & $\begin{array}{l}\text { @ 2011 S. Karger AG, Basel } \\
\text { ISSN 1662-6575 } \\
\text { www.karger.com/cro }\end{array}$ \\
\hline
\end{tabular}

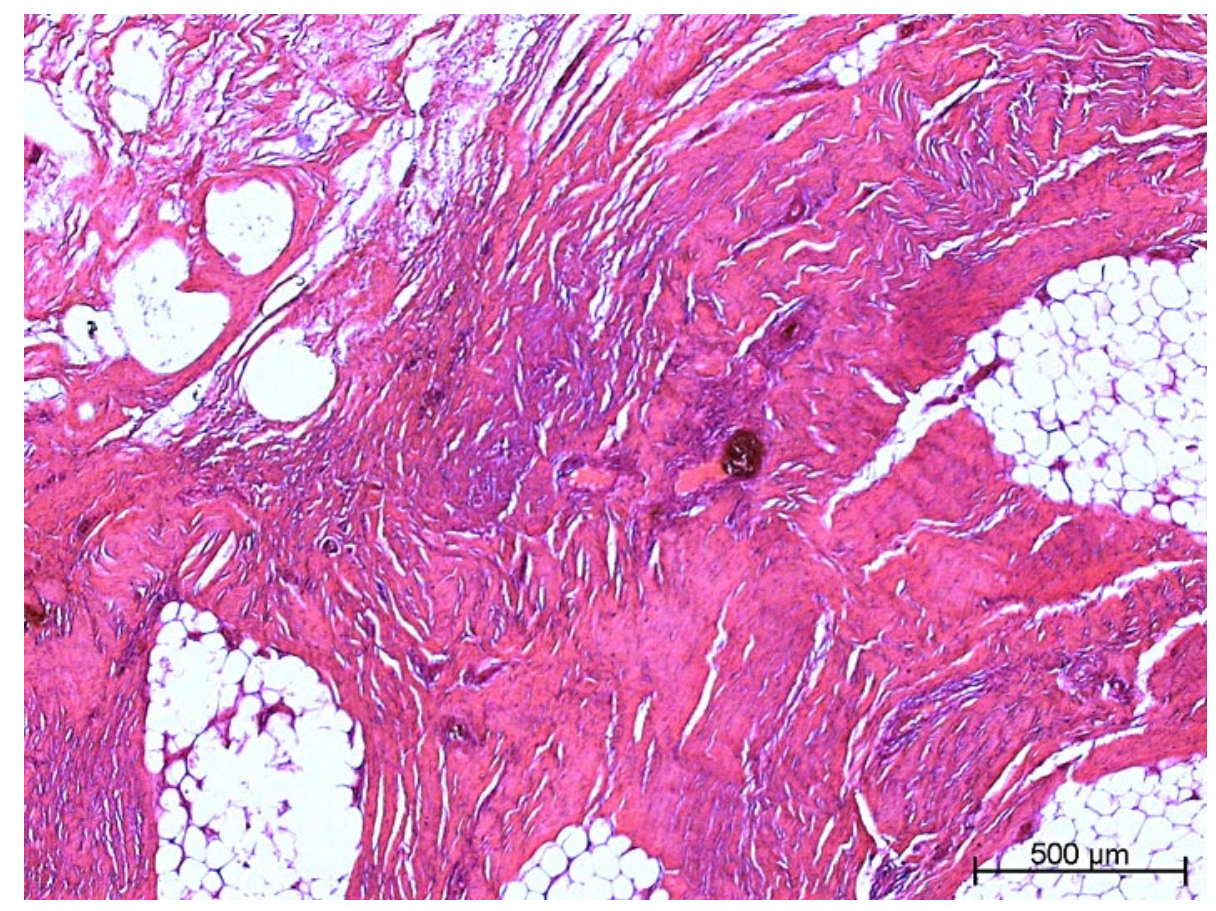

Fig. 4. HE staining of the synovial sarcoma. The tumor is characterized by a predominantly fasciculated growth pattern with spindle-shaped cells, with mostly oval nuclei and scarce cytoplasm. 


\section{References}

1 Koh KH, Cho EY, Kim DW, Seo SW: Multivariate analysis of prognostic factors in synovial sarcoma. Orthopedics 2009;32:824.

-2 Palmerini E, Staals EL, Alberghini M, Zanella L, Ferrari C, Benassi MS, Picci P, Mercuri M, Bacci G, Ferrari S: Synovial sarcoma: retrospective analysis of 250 patients treated at a single institution. Cancer 2009;115:2988 2998.

-3 Italiano A, Penel N, Robin YM, Bui B, Le Cesne A, Piperno-Neumann S, Tubiana-Hulin M, Bompas E, Chevreau C, Isambert N, Leyvraz S, du Chatelard PP, Thyss A, Coindre JM, Blay JY: Neo/adjuvant chemotherapy does not improve outcome in resected primary synovial sarcoma: a study of the French Sarcoma Group. Ann Oncol 2009;20:425-430.

-4 Canter RJ, Qin LX, Maki RG, Brennan MF, Ladanyi M, Singer S: A synovial sarcoma-specific preoperative nomogram supports a survival benefit to ifosfamide-based chemotherapy and improves risk stratification for patients. Clin Cancer Res 2008;14:8191-8197.

5 Spurrell EL, Fisher C, Thomas JM, Judson IR: Prognostic factors in advanced synovial sarcoma: an analysis of 104 patients treated at the Royal Marsden Hospital. Ann Oncol 2005;16:437-444.

6 Ferrari A, Gronchi A, Casanova M, Meazza C, Gandola L, Collini P, Lozza L, Bertulli R, Olmi P, Casali PG: Synovial sarcoma: A retrospective analysis of 271 patients of all ages treated at a single institution. Cancer 2004;101:627-634.

7 Lewis JJ, Antonescu CR, Leung DH, Blumberg D, Healey JH, Woodruff JM, Brennan MF: Synovial sarcoma: a multivariate analysis of prognostic factors in 112 patients with primary localized tumors of the extremity. J Clin Oncol 2000;18:2087-2094.

-8 Bergh P, Meis-Kindblom JM, Gherlinzoni F, Berlin O, Bacchini P, Bertoni F, Gunterberg B, Kindblom LG: Synovial sarcoma: identification of low and high risk groups. Cancer 1999;85:2596-2607.

$\checkmark 9$ Cheung MC, Zhuge Y, Yang R, Ogilvie MP, Koniaris LG, Rodríguez MM, Sola JE: Incidence and outcomes of extremity soft-tissue sarcomas in children. J Surg Res 2010;163:282-289.

10 Brennan B, Stevens M, Kelsey A, Stiller CA: Synovial sarcoma in childhood and adolescence: a retrospective series of 77 patients registered by the Children's Cancer and Leukaemia Group between 1991 and 2006. Pediatr Blood Cancer 2010;55:85-90.

11 Sultan I, Rodriguez-Galindo C, Saab R, Yasir S, Casanova M, Ferrari A: Comparing children and adults with synovial sarcoma in the Surveillance, Epidemiology, and End Results program, 1983 to 2005: an analysis of 1,268 patients. Cancer 2009;115:3537-3547.

12 Steinstraesser L, Hauk J, Jacobsen F, Stricker I, Steinau HU, Al-Benna S: Establishment of a synovial sarcoma model in athymic nude mice. In vivo 2011;25 [ahead of print].

13 Weiss SW, Goldblum J: Malignant soft tissue tumours of uncertain type; in Weiss SW, Goldblum J (eds): Enzinger and Weiss's soft tissue tumors. St. Louis, CV Mosby, 2001, pp 1483-1571.

14 Beck AH, West RB, van de Rijn M: Gene expression profiling for the investigation of soft tissue sarcoma pathogenesis and the identification of diagnostic, prognostic, and predictive biomarkers. Virchows Arch 2010:456:141-151

15 Al-Benna S, Steinsträsser L: Postablative reconstruction is better terminology than oncoplastic surgery. Plast Reconstr Surg 2009;124:463e-464e.

-16 Ohno Y, Tanaka K, Kanematsu T, Noguchi M, Okada M, Kamitamari A, Hayashi N: Reconstruction of a pelvic floor defect using a pedicled tensor fascia lata flap: a new technique to prevent radiation injury for pediatric patients with advanced pelvic tumors. J Pediatr Surg 2008;43:947-950. 